\title{
STUDI TENTANG RUTE, JANGKAUAN DAN PERMINTAAN TERHADAP BECAK KAYUH DI KECAMATAN PADANG UTARA
}

\author{
Lenni Ati Harahap ${ }^{1}$, Endah Purwaningsih ${ }^{2}$ \\ Program Studi Pendidikan Geografi \\ Fakultas Ilmu Sosial Universitas Negeri Padang \\ Email: lenniatiharahap93@gmail.com
}

\begin{abstract}
Abstrak
Artikel ini bertujuan (1) mendeskripsikan rute, jangkauan dan permintaan pelanggan becak kayuh di Padang Utara. Kelurahan Ulak Karang Utara sudah ada penetapan/pembagian rute. Metode Deskriptif Kualitatif. Informan tukang becak dan pelanggan becak. Teknik analisis snowball sampling. Hasil: peta rute dan jangkauan becak kayuh. Frekuensi permintaan jasa becak per hari 5-20 putaran, pendapatan Rp. 50.000,- minggu 80-100 putaran, pendapatan Rp. 350.000,- bulan 300-400 putaran, pendapatan Rp. 1.200.000,- karakteristik pelanggan: bapak-bapak, ibuk-ibuk, neneknenek, mahasiswa dan pelajar. Tanggapan masyarakat terhadap becak kayuh sangat bagus, lebih suka menggunakan jasa angkut becak kayuh dari pada ojek motor.
\end{abstract}

Kata Kunci: Rute, Jangkauan, Permintaan Becak Kayuh

\section{Abstract.}

This article aims (1) describe pedicab route range and pedal rickshaw customers pedal Subdistrict North Padang. District Ulak Karang Utara Reef has beeb established route. Method used descriptive qualitative. Informant is pedicap pedal and customers. Technique data analysis snowball sampling. Results : pedicab route and range map. Frequency of demand for pedicab driver services in both urban villages within 5-20 rounds, Rp. 50.000 income. Matter of weeks 80-100 pairs with average income Rp.350.000,- frequency the count 300-400 rounds with average income of approximately Rp.1.200.000,-. Characteristics of pedicap pedal: fathers, mother, grandmother and student. Response community is good carriage from motorcycle taxi. As for District Ulak Karang Utara is already division of blocks for each route/path for freight services.

Keywords: Route, Range, Demande Pedicas Pedicabs Pedal

\footnotetext{
${ }^{1}$ Mahasiswa Geografi Fakultas Ilmu Sosial Universitas Negeri Padang

${ }^{2}$ Dosen Geografi Fakultas Ilmu Sosial Universitas Negeri Padang,Dra. Endah Purwaningsih, M.Sc
} 


\section{PENDAHULUAN}

Becak termasuk salah satu alat transportasi darat yang masih tradisional, sebagai salah satu transportasi yang mempunyai nilai tersendiri serta masih diminati oleh sebagian orang, terutama becak kayuh yang merupakan kendaraan yang digerakkan oleh tenaga manusia, keberadaan becak kayuh ini menggambarkan adanya kebutuhan manusia akan jasa angkutan yang melayani dari jarak pendek/lokal. Seiring bertambahnya jumlah penduduk yang semakin pesat serta dengan tersedianya fasilitas kota yang lebih sempurna mengakibatkan kebutuhan akan transportasi semakin meningkat. Sementara itu perluasan kota menimbulkan kecenderungan permukiman jauh dari tempat kerja atau pusat kegiatan dan masih terdapatnya lokasi-lokasi yang tidak terjangkau oleh transportasi yang ada.

Oleh karena itu kebutuhan masyarakat terhadap angkutan yang serba cepat, praktis dan ekonomis tidak dapat dihindarkan. Betor dan ojek merupakan pesaing utama angkutan becak kayuh dan angkutan motor lainnya, masyarakat lebih cenderung memilih menaiki betor atau ojek dibandingkan dengan becak kayuh, karena betor dan ojek dinilai lebih cepat dan ekonomis dibandingkan angkutan becak kayuh. Hal ini jelas-jelas dapat mengurangi pendapatan para tukang becak kayuh, walaupun demikian masih ada masyarakat yang memilih becak kayuh sebagai sarana angkutan walaupun jumlahnya sedikit. Selain itu masih ada beberapa tukang becak kayuh yang masih bertahan sebagai pengayuh becak walaupun pendapatannya kurang mampu untuk memenuhi kebutuhan sehari-hari mereka.

Menurut Julius (2009:4) Transportasi tradisional dapat didefinisikan sebagai kendaraan tradisional. Kendaraan tradisional adalah alat transportasi yang tidak menggunakan tenaga mesin tetapi menggunakan tenaga manusia ataupun hewan sebagai penggeraknya. Bentuk kendaraan-kendaraan tersebut beragam, tetapi mempunyai beberapa kesamaan, yaitu beroda (kecuali tandu) dan memiliki tempat untuk mengangkut penumpang maupun barang. Jadi transportasi tradisional yang berupa bentuk kendaraan tradisional adalah alat transportasi yang tidak menggunakan tenaga mesin tetapi menggunakan tenaga manusia atau hewan sebagai penggerak dan sebagai usaha mengangkut subjek dari suatu tempat ke tempat lain, dimana tempat lain ini objek tersebut lebih bermanfaat atau dapat berguna untuk tujuan-tujuan tertentu untuk mendukung aktivitas manusia.

Sani (2010:28) mengungkapkan bahwa "sistem jaringan (route) merupakan satu kesatuan jaringan jalan yang terdiri dari sistem jaringan jalan primer dan sistem jaringan jalan sekunder yang terjalin dalam hubungan hierarki". Sistem jaringan jalan disusun dengan mengacu pada rencana tata ruang wilayah dengan memperhatikan keterhubungan antar kawasan dan atau dalam kawasan perkotaan dan kawasan perdesaan. Menurut Bintarto (1987) 
Jaringan dapat diartikan sebagai suatu sistem garis yang menghubungkan himpunan titik-titik. Suatu jaringan dapat berbentuk material atau alur-alur sungai ataupun jaringan transportasi. Jhotin Khisty (2003:102) mengemukakan bahwa pelayanan angkutan umum dapat diklasifikasikan menjadi tiga kelompok berdasarkan jenis rute dan perjalanan yang dilayaninya.

1) Angkutan jarak pendek ialah pelayanan kecepatan rendah di dalam kawasan sempit dengan densitas perjalanan tinggi, seperti kawasan perdagangan utama (central business district-CBD).

2) Angkutan kota, yang merupakan jenis yang paling lazim, melayani orang-orang yang membutuhkan transportasi di dalam kota. 3) Angkutan regional melayani perjalanan jauh, berhenti beberapa kali dan umumnya memiliki kecepatan tinggi. Sistem kereta api cepat dan bus ekspres termasuk ke dalam kategori ini.

Aksessibilitas merupakan derajat keterjangkauan suatu lokasi untuk mencapai lokasi lainnya yang dikaitkan dengan gerak. Dimensi jarak dapat diukur dari : a) Jarak fisik atau geometrik yang diukur dengan kilometer, b) Jarak waktu yang dapat diukur dengan satuan waktu dan c) Jarak ekonomi yang diukur dengan ongkos atau biaya yang dikonversikan dengan uang untuk memindahkan barang dari satu tempat ke tempat lainnya. Aksesibilitas mempunyai kaitan sangat erat dengan lokasi dan jarak yaitu derajat tingkat kemudahan ke lokasi lain. Artinya peran jarak dan waktu sangat berpengaruh dalam menentukan derajat aksesibilitas ini. Anwar (1999) mengungkapkan bahwa transportation is measure of the relation between areas (transportasi adalah suatu kegiatan yang menghubungkan antara satu daerah dengan daerah yang lain). Selanjutnya Anwar (1999) juga mengemukakan bahwa kegiatan transportasi muncul karena tiga faktor geografis yakni 1) jarak (distance), 2) melengkapi kebutuhan (complementary) dan 3) kesempatan untuk intervensi (intervening opportunity).

Transportasi muncul karena kesempatan berintervensi (intervening opportunity). Intervensi sifatnya sebagai kegiatan pengarahan manusia dari suatu daerah ke daerah lain guna berbagai kepentingan. Keterjangkauan sangat erat kaitannya dengan faktor-faktor interaksi desa dan kota. Menurut Bakaruddin (2010:42) bahwa adanya kemudahan transfer/pemindahan dalam ruang (spacial transfer ability) artinya kemudahan transfer atau pemindahan dalam ruang baik manusia, informasi ataupun barang sangat bergantung dengan faktor jarak, biaya angkasa (transportasi) dan kelancaran prasarana transportasi. Jadi semakin mudah transferbilitas, maka akan semakin besar arus komoditas. Dengan lancarnya transportasi dari desa ke kota maka akan mendorong timbulnya kerja sama antar wilayah di Indonesia.

Kanafani dalam Miro (2005:48) Analisis permintaan transportasi merupakan proses yang berusaha menghubungkan antara kebutuhan akan jasa transportasi dengan aktivitas sosial 
ekonomi yang menimbulkan kebutuhan transportasi tersebut. Selanjutnya Kanafani (2005) menyatakan bahwa dalam proses ini, tipe, tingkat dan lokasi aktivitas manusia harus dihubungkan dengan kebutuhan (keinginan) untuk melakukan pergerakan dari orang dan barang pada simpul-simpul dalam ruang yang ada tempat dilakukannya aktivitas sosial ekonomi. Inilah sasaran yang akan dituju oleh kegiatan analisis permintaan transportasi, agar terjadi suatu kondisi ideal berupa keseimbangan antara jumlah kebutuhan akan jasa transportasi dengan banyaknya fasilitas transportasi yang harus disediakan untuk melayani masyarakat. Untuk mencapai tujuan utama (keseimbangan) atau paling tidak mendekati keseimbangan, antara jumlah kebutuhan akan jasa transportasi dengan banyaknya fasilitas pelayanan transportasi yang harus disediakan untuk melayani masyarakat, dilakukanlah semacam analisis atau telaah guna menaksir berapa jumlah kebutuhan akan jasa transportasi sekaligus meramalkan bagaimana gelagat perubahan jumlah kebutuhan akan jasa transportasi ini pada masa mendatang, serta meniliti faktor-faktor apa saja yang berperan sebagai penyebab timbulnya perubahan dalam jumlah kebutuhan akan jasa transportasi.

Adanya permintaan jasa transportasi dari sektor-sektor lain menyebabkan timbulnya penyediaan jasa transportasi, atau dapat dikatakan bahwa penyedia jasa transportasi itu berasal dari atau diturunkan dari permintaan sektor-sektor lain, maka permintaan jasa transportasi sering disebut derived demand. Permintaan akan jasa transportasi dari penumpang atau orang timbul oleh akibat kebutuhan orang untuk melakukan perjalanan dari suatu lokasi ke lokasi lainnya dalam rangka beraktivitas seperti bekerja, sekolah, belanja dan lain sebagainya. Sifat kebutuhan ini diperlihatkan oleh kenyataan sehari-hari, dimana sering terjadi perjalanan dalam rangka mencapai suatu tujuan tertentu (tujuan sebenarnya yang ingin dicapai).

Jadi kapasitas transportasi harus disediakan secara seimbang dengan permintaan agar mampu melayani atau memenuhi kebutuhan hidup sehari-hari yang berorientasi kepada kebutuhan masa depan. Permintaan transportasi, atau dengan kata lain kebutuhan manusia dan barang akan jasa transportasi, bukanlah merupakan kebutuhan langsung (tujuan akhir yang diinginkan). Sebenarnya kebutuhan akan jasa transportasi timbul disebabkan oleh adanya keinginan untuk mencapai/memenuhi tujuan lain yang sebenarnya. Jasa trasnportasi hanyalah media perantara untuk mencapai tujuan lain. Miro (2005:48) mengemukakan Oleh sebab itu permintaan akan jasa transportasi disebut bersifat tidak langsung yang dikenal dengan istilah populer permintaan turunan atau drived demand.

$$
\text { Zulfiar Sani (2010:144) }
$$

mengungkapkan bahwa ada dua pendekatan pokok untuk mengatasi masalah fluktuasi permintaan, yaitu menyesuaikan tingkat kapasitas untuk memenuhi variasi permintaan dan mengelola tingkat permintaan. 
Berdasarkan uraian masalah di atas peneliti tertarik melakukan penelitian ini dikarenakan ingin melihat bagaimana rute dan jangkauan yang dilewati setiap harinya. Kemudian bagaimana permintaan pelanggan terkait penyedia jasa (becak kayuh), jika permintaan lebih kecil dari pada penyedia jasa maka akan sangat berpengaruh terhadap pemenuhan kebutuhan primer para tukang becak kayuh. Bertolak dari pemikiran tersebut dipandang perlu suatu kajian tentang angkutan becak kayuh yang dituangkan dalam satu judul penelitian yaitu,

"Studi Tentang Rute, Jangkauan dan Permintaan Terhadap Becak Kayuh di Kecamatan Padang Utara".

\section{METODE PENELITIAN}

Penelitian ini bertujuan untuk menemukan, mengembangkan dan menguji kebenaran suatu masalah sehingga masalah dapat dipecahkan. Penelitian ini menggunakan langkahlangkah dalam menetapkan dan mengumpulkan data serta informasi dan sampai mengambil kesimpulan untuk mencapai kesempurnaan.

Sesuai dengan tujuan dan permasalahan penelitian ini menggunakan metode penelitian Deskriptif Kualitatif yaitu penelitian yang bertujuan memberikan gambaran, membahas dan mendeskripsikan tentang rute, jangkauan dan permintaan becak kayuh. Oleh karena itu penelitian kualitatif yang mampu menjelaskan dengan tipe penelitian deskriptif. Menurut Sugiyono (2005) penelitian deskriptif adalah suatu bentuk penelitian yang paling dasar ditujukan untuk mendeskripsikan atau menggambarkan fenomena yang ada, baik fenomena yang bersifat alamiah ataupun rekayasa manusia. Sedangkan Tika (1997 : 115) menjelaskan bahwa deskriptif kualitatif diperlukan untuk menjelaskan fenomena-fenomena sosial. Data dikumpulkan melalui observasi lapangan, wawancara dan analisis yang disusun ke dalam teks terdiri dari reduksi, penyajian dan perbaikan kesimpulan. Berdasarkan pertanyaan penelitian dan tujuan penelitian yang telah dijelaskan di atas, maka penelitian ini menggunakan jenis penelitian deskriptif kualitatif. Moleong (2007) Deskriptif kualitatif adalah prosedur penelitian yang menghasilkan data deskriptif berupa kata-kata tertulis atau lisan dari orang-orang dan perilaku yang dapat diamati. Dimana metode ini digunakan untuk mendeskripsikan tentang keberadaan tukang becak kayuh di Kecamatan Padang utara. Pemecahan dari masalah maka digunakan data primer dan data sekunder. Data primer didapat melalui daftar pertanyaan yang disusun sendiri sesuai keputusan dan melalui wawancara oleh peneliti. Data selanjutnya yaitu data sekunder yang dikumpulkan dari Kantor Kecamatan maupun Kantor Kelurahan. Ada tiga kelurahan/lokasi di Padang Utara yang bekerja sebagai tukang becak kayuh tapi peneliti hanya mengambil dua kelurahan. Alasan peneliti memilih dua lokasi penelitian adalah karena keterbatasan waktu dan biaya, Penelitian ini dilakukan di kedua kelurahan yang ada di Kecamatan Padang Utara yakni: Air Tawar Timur: 
tukang becak kayuh sebanyak 11 orang dan Ulak Karang Utara: tukang becak kayuh sebanyak 8 orang. Informan adalah orang yang memberikan informasi. Dengan pengertian ini maka informan dapat dikatakan sama dengan responden, apabila pemberian keterangannya karena dipancing oleh peneliti, (Suharsini Arikunto : 2006).

Penentuan informan penelitian dengan menggunakan teknik snowball sampling yaitu teknik pengumpulan sampel yang mula-mula jumlahnya kecil, kemudian membesar. Hal ini dilakukan karena dari jumlah sumber data yang sedikit tersebut belum mampu memberikan data yang memuaskan, maka mencari orang lain lagi yang dapat digunakan sebagai sumber data. Dengan demikian jumlah sampel sumber data akan semakin besar, seperti bola salju yang menggelinding, lama lama menjadi besar (Sugiyono, 2011 : 219).

Sehubungan dengan penelitian ini, maka yang dijadikan subjek penelitian adalah tukang becak kayuh, mahasiswa, anak-anak, ibu-ibu, bapak-bapak atau masyarakat setempat yang pernah menggunakan jasa becak kayuh. Agar data yang dibutuhkan dapat dikumpulkan dengan baik maka teknik pengumpulan data yang digunakan dalam penelitian ini adalah: wawancara, observasi dan dokumentasi Analisis data pada penelitian kualitatif dimulai dari pengumpulan data sampai kepada penarikan kesimpulan penelitian. Oleh karena itu peneliti merupakan instrumen utama dalam penelitian. Data yang telah dikumpulkan setiap hari selama penelitian akan dibuatkan laporan lapangan, untuk mengungkapkan data apa yang masih perlu dicari, pertanyaan apa yang belum dijawab, metode apa yang harus digunakan untuk mendapatkan informasi baru, dan kesalahan apa yang perlu diperbaiki, serta data yang mana yang tidak diperlukan. Mulai dari reduksi data dan penarikan kesimpulan. Keabsahan data atau kepercayaan terhadap data hasil penelitian kualitatif antara lain dilakukan dengan perpanjangan pengamatan, meningkatkan ketekunan dan menggunakan bahan referensi (Sugiyono : 2005).

\section{HASIL TEMUAN}

a. Air Tawar Timur

Dari hasil wawancara dapat diketahui bahwa rute becak kayuh dimulai dari titik mangkal becak kayuh di jl. Hamka, Jl. Polonia, Jl. Ngurah Rai I, II dan III, Jl. Pinang Sori I, II, dan III, Jl. Kijang I, II dan III, Jl. Tapi Aiya, Jl. Mutiara, Jl. Padang Kemiling, Jl. Talang Betutu, Jl. Simpang Tigo, Jl. Gapura, Jl. Belang Bintang, Jl. Bosnia, jl. Tunggul Hitam, Jl. Palmerah, Jl. Seranti, J1. Sentani, J1. Bonco dan J1. Garuda). Terkait rute yang paling sering dilalui para tukang becak kayuh adalah memasuki jalan Pinang Sori I dan Pinang Sori III. Setelah dilakukan survei ke lapangan bahwasanya daerah Pinang Sori dominan anak kos yang tidak memiliki kendaraan. Berikut adalah rute peta Air Tawar Timur dan Ulak Karang Utara 


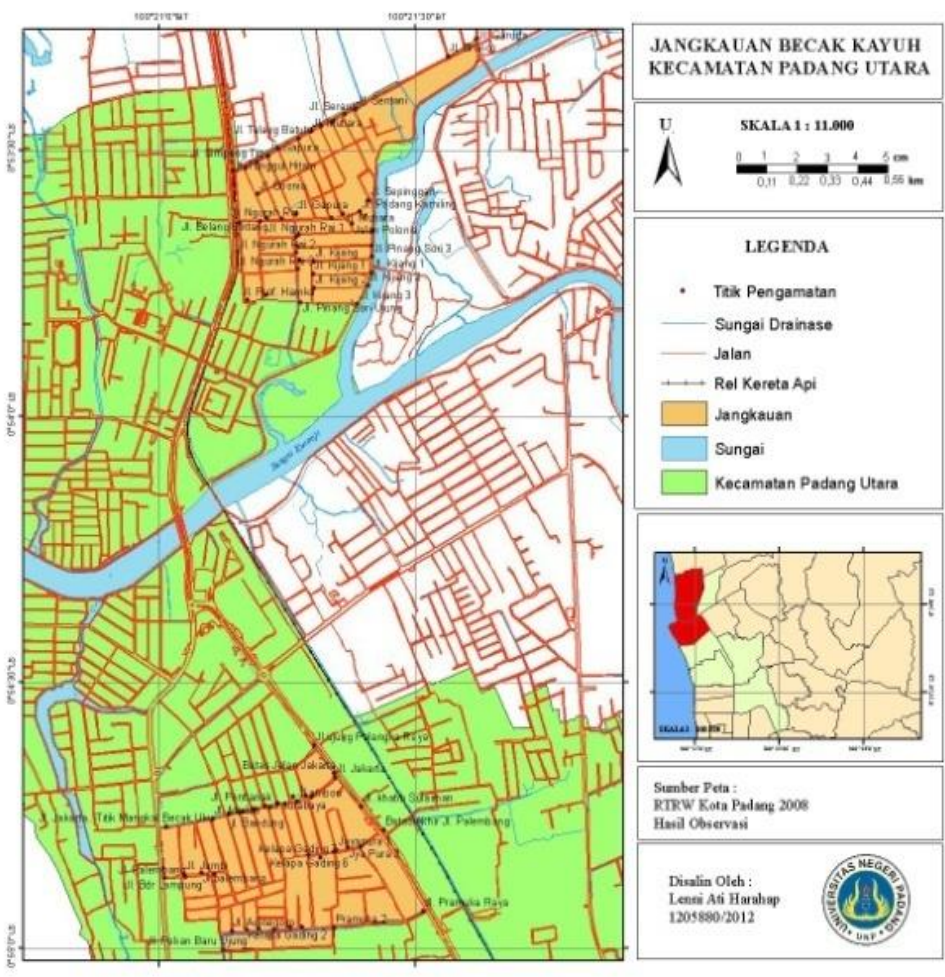

Berdasarkan peta di atas dapat dilihat rute-rute yang dilewati becak kayuh di kedua kelurahan dan batasbatas jangkauan becak kayuh mulai dari jangkauan terdkat maupun jangkauan paling jauh yakni jangkauan becak kayuh paling dekat yaitu jl. Ngurah Rai (rumah warung makan) dan jangkauan yang paling jauh yaitu jl. Garuda.

Berdasarkan hasil wawancara di atas dapat disimpulkan bahwa frekuensi tukang becak kayuh per harinya 5-20 kali putaran dengan hasil pendapatan yaitu lebih kurang Rp. 50.000,- per orang. Dalam satu minggu mereka bisa bolak-balik mengantar penumpang sampai 80-100 kali putaran dengan ratarata pendapatan Rp. 350.000,- per minggunya. Sedangkan frekuensi dalam hitungan bulan bisa sampai 300-400 kali putaran dengan rata-rata pendapatan lebih kurang Rp.
1.200.000,- tukang becak. Berikut tabel rata-rata pendapatan Becak Kayuh:

Tabel 1. Data Usia dan Pendapatan Tukang Becak Kayuh Air Tawar Timur

\begin{tabular}{|c|l|r|c|}
\hline No & Nama & $\begin{array}{c}\text { Usia } \\
\text { (tahun) }\end{array}$ & $\begin{array}{c}\text { Rata- } \\
\text { rata/bulan } \\
\text { (Rp) }\end{array}$ \\
\hline 1 & Wondo & 45 & 1.125 .000 \\
\hline 2 & Mawi & 58 & 1.150 .000 \\
\hline 3 & Iral & 26 & 655.000 \\
\hline 4 & Irul & 48 & 1.275 .000 \\
\hline 5 & Erik & 46 & 1.150 .000 \\
\hline 6 & Feri & 32 & 1.050 .000 \\
\hline 7 & Enek & 44 & 1.175 .000 \\
\hline 8 & Udin & 36 & 900.000 \\
\hline 9 & Mus & 45 & 1.150 .000 \\
\hline 10 & Yon & 47 & 1.075 .000 \\
\hline 11 & Siral & 48 & 1.125 .000 \\
\hline \multicolumn{3}{|c|}{ Sumber: data primer tahun 2017 } \\
\hline \multicolumn{3}{|c|}{ Jika ding }
\end{tabular}

Jika dilihat dari segi pendapatan ternyata itu tidak bisa sepenuhnya memenuhi kebutuhan tukang becak kayuh yang jika kita berpedoman pada pemenuhan kebutuhan manusia menurut intensitas kegunaan yakni, (1) kebutuhan primer (sandang, pangan, papan, kesehatan dan pendidikan). (2) kebutuhan sekunder (berbudaya dan bermasyarakat) dan (3) kebutuhan tersier (kebutuhan akan barang mewah dan lebih kepada status sosial). Solusi untuk dapat memenuhi kebutuhan harian menurut intensitas kegunaan tukang becak kayuh adalah dengan adanya pengurangan pekerja yang mangkal di jalan Hamka, namun itu juga akan mengakibatkan bertambahnya angka pengangguran di Kelurahan Air Tawar Timur yang merupakan masalah baru. Berdasarkan hasil wawancara dengan pelanggan becak kayuh maka dapat disimpulkan bahwa masyarakat lebih memilih naik becak kayuh dari 
pada ojek motor dengan alasan-alasan yang telah dipaparkan di atas. Beberapa alasan masyarakat diantaranya yaitu lebih aman, nyaman naik becak, tidak panas, lebih lapang dan tidak mencemarkan polusi udara. Walaupun tanggapan masyarakat positif terhadap jasa becak kayuh namun jika kita lihat lagi kepada pendapatan tukang becak kayuh itu belum bisa menyeimbangi antara pendapatan dengan pemenuhan kebutuhan sehari-hari dalam artian masih belum mampu sepenuhnya memenuhi kebutuhan hidup para tukang becak kayuh di Kelurahan Air Tawar Timur.

\section{b. Ulak Karang Utara (UKU)}

Berdasarkan hasil wawancara di atas dapat disimpulkan rute-rute yang dilewati becak kayuh yaitu: J1. Jakarta (titik mangkal becak kayuh), Jl. Palembang, jl. Jambi, j1. Bandar Lampung, jl. Pekanbaru, j1. Medan, jl. Bandung, jl. Ujung Padang, jl. Samarinda, jl. Semarang, jl. Menado, jl. Yogyakarta, jl. Pontianak, jl. Surabaya, jl. Banjarmasin, jl. Denpasar, jl. Palangkaraya, jl. Ambon, j1. Mataram, jl. Jayapura I, II dan III, jl. Pramuka Raya, jl. Kelapa Gading I, II, III, IV, V, VI, VI dan VIII, jl. Adinegoro, dan jl. Khatib Sulaiman (depan Transmart). Rute yang paling sering dilewati di kelurahan ini yaitu daerah jl. Jakarta.

Adapun untuk melihat jangkauan becak kayuh Ulak Karang Utara dapat dilihat dari hasil wawancara atau penjelasan tukang becak kayuh yang dituangkan ke dalam peta di atas. Dari peta di atas bisa dilihat jangkauan becak kayuh Ulak Karang Utara terdekat dan jangkauan becak kayuh paling jauh.
Jangkauan paling dekat yaitu jl. Palembang dan jl. Medan sedangkan jangkauan paling jauh yaitu jl. Pramuka Raya. Sedangkan untuk tarif/biaya itu sebesar Rp.5.000,- jauh maupun dekat.

Berdasarkan hasil wawancara dapat disimpulkan bahwa frekuensi tukang becak kayuh per harinya 5-14 kali putaran dengan hasil pendapatan yaitu lebih kurang Rp. 50.000,- per orang. Dalam satu minggu mereka bisa bolak-balik mengantar penumpang sampai 80-100 kali putaran dengan ratarata pendapatan Rp. 350.000,- per minggunya. Sedangkan frekuensi dalam hitungan bulan bisa sampai 150-350 kali putaran dengan rata-rata pendapatan lebih kurang Rp. 1.200.000,- masing-masing tukang becak. Untuk lebih jelasnya tentang rata-rata pendapatan per bulan para tukang becak kayuh dapat dilihat pada tabel berikut ini:

Tabel 2. Data Usia dan Pendapatan Tukang Becak Kayuh Ulak Karang Utara

\begin{tabular}{|c|l|r|r|}
\hline No & Nama & Umur & $\begin{array}{r}\text { Rata- } \\
\text { rata/bulan } \\
\text { (Rp) }\end{array}$ \\
\hline 1 & Nando & 42 & 1.250 .000 \\
\hline 2 & Anto & 52 & 1.190 .000 \\
\hline 3 & Ivan & 32 & 1.150 .000 \\
\hline 4 & Heri & 55 & 1.500 .000 \\
\hline 5 & Hendra & 51 & 1.170 .000 \\
\hline 6 & Edi & 55 & 700.000 \\
\hline 7 & Andre & 49 & 1.350 .000 \\
\hline 8 & Khoir & 34 & 1.270 .000 \\
\hline
\end{tabular}

Sumber : data Primer tahun 2017

Jika dilihat dari segi pendapatan ternyata tidak bisa sepenuhnya memenuhi kebutuhan tukang becak 
kayuh yang jika kita berpedoman pada pemenuhan kebutuhan manusia menurut intensitas kegunaan yakni, kebutuhan primer (sandang, pangan, papan, kesehatan dan pendidikan), (2) kebutuhan sekunder (berbudaya dan bermasyarakat) dan (3) kebutuhan tersier (kebutuhan akan barang mewah dan lebih kepada status sosial). Solusi untuk dapat memenuhi kebutuhan harian tukang becak kayuh adalah dengan adanya pengurangan pekerja yang mangkal di jl. Jakarta ini, namun itu juga akan mengakibatkan bertambahnya angka pengangguran di Kelurahan Ulak Karang Utara.

Dari hasil wawancara dengan pelanggan becak kayuh maka dapat disimpulkan bahwa masyarakat sekitar akan naik becak kayuh jika melewati rute/jalur khusus becak kayuh, begitu juga sebaliknya jika pelanggan melewati jalur becak motor maka mereka harus menggunakan jasa becak motor dalam artian tergantung tujuan masing-masing dari pelanggan dan jika ada pelanggan yang mau naik becak motor atau becak kayuh tapi belum tahu aturan jalur dari becak maka tukang becak akan mengantarkan ke pangkalan dan langsung diambil alih oleh blok yang seharusnya. Alasan blok-blok ini diatur oleh organisasi yaitu agar saling membantu satu sama lain. Rute/jalur yang sudah ditentukan tidak boleh dimasuki atau melewati jalur yang sudah ada agar tidak terjadi kesalahfahaman dan supaya punya jalan rezeki masing-masing becak.

\section{PERBANDINGAN ANTARA DUA KELURAHAN}

a. Air Tawar Timur

Berdasarkan hasil wawancara yang sudah dilakukan peneliti, maka diketahuilah beberapa perbedaan antara dua kelurahan tersebut. Di kelurahan Air Tawar Timur terdapat tukang becak kayuh sebanyak 11 orang. Status kepemilikan dari becak yang mereka gunakan untuk mencari nafkah adalah milik orang lain (pengusaha becak kayuh) dan dikenakan tarif Rp. 10.000,per hari besar-kecilnya pendapatan yang mereka dapatkan. Sebagian tukang becak kayuh pendapatannya paling rendah per harinya sebesar Rp. 25.000,sedangkan pendapatan paling tinggi sebesar Rp. 80.000,-. Jika dirata-ratakan pendapatan tukang becak kayuh berkisar Rp. 1.200.000,- (sudah di luar uang sewa becak). Tarif/ongkos jasa becak per orang adalah sebesar Rp. 3.000,- jauh maupun dekat, becak kayuh bisa menampung sewa 1-3 orang. Sedangkan jam kerja para tukang becak kayuh mulai pada jam 07.00 pagi sampai dengan jam 19.00 malam. Tidak ada perbedaan jalur atau rute baik becak kayuh maupun ojek motor bisa melewati rute mana saja tergantung permintaan dari pemakai jasa.

b. Ulak Karang Utara

Di kelurahan Ulak Karang Utara terdapat tukang becak kayuh sebanyak 9 orang. Perbedaan yang bisa kita lihat ada pada organisasi becak kayuh yakni Jasa Angkutan Becak Pemuda Ulak Karang dan Sekitarnya (JABPUS) fungsinya untuk keamanan jasa becak kayuh jika ada terjadi kesalahfahaman antara becak kayuh dengan becak 
motor. Kemudian status kepemilikan becak kayuh, di Ulak Karang becak yang mereka gunakan untuk mencari nafkah adalah milik sendiri, tidak ada uang sewa yang harus meraka setorkan, dan dikenakan tarif/ongkos jasa becak kayuh sebesar Rp.5.000,- jauh maupun dekat. Pendapatannya paling rendah per harinya sebesar Rp. 25.000,- sedangkan pendapatan paling tinggi sebesar Rp. 50.000-75.000,-. Jika dirata-ratakan pendapatan tukang becak kayuh per bulannya berkisar Rp. 1.200.000,- Tarif becak per orang adalah sebesar Rp.5.000,- jauh maupun dekat. Bentuk becaknya sama begitu juga daya tampungnya, meraka bisa menampung sewa 1-3 orang penumpang. Sedangkan jam kerja para tukang becak kayuh di Kelurahan Ulak Karang berbeda dengan jam kerja para tukang becak kayuh Kelurahan Air Tawar Timur. Jam kerja di Ulak Karang Utara mulai dari jam 06.00 pagi sampai dengan jam 22 malam (sebagian tukang becak). Kemudian perbedaan lainnya ada pada jalur/rute. Rute becak kayuh dan becak motor Ulak Karang Utara telah ditentukan oleh pihak-pihak organisasi yang mereka ciptakan guna ketertiban agar tidak saling mengambil sewa orang, mereka menyebutnya pembagian jalur/rute sama dengan pembagian rezeki.

\section{PEMBAHASAN}

Pertama, rute becak kayuh Air Tawar Timur mulai dari jalan Hamka (tempat mangkal becak kayuh), masuk ke jalan Polonia, jika kita belok ke kanan masuk Jl. Ngurah Rai (I, II dan III), Jl. Pinang Sori (I, II dan III), Jl.
Kijang (I, II dan III), Jl. Tapi Aiya. Jl. Belang Bintang, Jl. Simpang Tigo, Jl. Gapura, Jl. Talang Betutu, Jl. Mutiara, Jl. Padang Kemiling dan Jl. Sepinggan. Jika kita naik ke atas masuk jl. Tapi Aiya lurus sedikit kita akan tembus ke Jl. Sentani, Jl. Seranti, Jl. Tunggul Hitam, sampai ke Jl. Bronco dan Jl. Garuda). Lebih sering ke arah Jl. Pinang Sori karena disana banyak masiswa yang tidak memiliki motor.

Sedangkan rute becak kayuh Ulak Karang Utara mulai dari jl. Jakarta (titik mangkal becak kayuh) Jl. Palembang, jl. Jambi, jl. Bandar Lampung, jl. Pekanbaru, jl. Medan, jl. Bandung, jl. Ujung Pandang, jl. Samarinda, jl. Semarang, jl. Menado, jl. Yogyakarta, jl. Pontianak, jl. Surabaya, jl. Banjarmasin, jl. Denpasar, jl. Palangkaraya, jl. Ambon, jl. Mataram, jl. Jayapura I, II dan III, jl. Pramuka Raya, jl. Kelapa Gading I, II, III, IV, V, VI, VI dan VIII, jl. Adinegoro, dan jl. Khatib Sulaiman (depan Transmart). Rute yang paling sering dilewati di kelurahan ini yaitu Jl. Jakarta.

Setiap simpang jalan diambil titik koordinat kemudian ditarik garis lurus dari titik mangkal ke titik jalur selanjutnya kemudian proses melalui penalaran yang bertolak dai sejumlah titik khusus menuju kesimpulan umum yang mengikat seluruh titik yang diselidiki (generalisasi).

Kedua, jangkauan becak kayuh dapat diukur dengan ongkos, atau biaya. Menurut Suasti (1995) aksessibilitas merupakan derajat keterjangkauan suatu lokasi untuk mencapai lokasi lainnya yang dikaitkan dengan gerak. Dimensi jarak dapat diukur dari : a) Jarak fisik 
atau geometrik yang diukur dengan kilometer, b) Jarak waktu yang dapat diukur dengan satuan waktu dan c) Jarak ekonomi yang diukur dengan ongkos atau biaya yang dikonversikan dengan uang untuk memindahkan barang/orang dari satu tempat ke tempat lainnya. Jadi jangkauan becak kayuh di kedua kelurahan dapat diukur dengan ongkos atau biaya/tarif yang dikonversikan dengan uang yang kemudian dituangkan ke dalam sebuah peta dengan menghubungkan titik koordinat yang diambil langsung dari lapangan. Yang kemudian dapat dilihat jangakauan terdekat dan jangkauan paling jauh.

Semakin jauh jangkauan besar kemungkinan semakin besar pendapatan para tukang becak kayuh. Karna jangkauan yang jauh akan mempengaruhi pendapatan tapi tidak dengan hidup mereka. Setelah dilakukan wawancara ke lapangan ternyata jangkauan para tukang becak hampir sama, para tukang becak kayuh telah menetapkan jangkauan terjauh sehingga pendapatan para tukang becak kayuh hampir sama kadang banyak dan kadang sedikit. Penetapan jangkauan ini sengaja dibuat agar tidak terjadinya pengaliahan penumpang ke becak lain.

Ketiga Berdasarkan hasil wawancara di Kelurahan Air Tawar Timur dapat disimpulkan bahwa frekuensi tukang becak kayuh per harinya 5-20 kali putaran dengan hasil pendapatan dalam sehari yaitu lebih kurang Rp. 50.000,- per orang. Dalam satu minggu mereka bisa bolak-balik mengantar penumpang sampai 80-100 kali putaran dengan rata-rata pendapatan Rp. 350.000,- per minggunya. Sedangkan frekuensi dalam hitungan bulan bisa sampai 300-400 kali putaran dengan rata-rata pendapatan lebih kurang Rp. 1.200.000,- masing-masing tukang becak. Sedangkan untuk karakteristik pelanggan becak kayuh mulai dari bapak-bapak, ibu-ibu, mahasiswa, nenek-nenek dan siswa pelajar.

Terkait alasan masyarakat memilih becak kayuh sebagai jasa angkutan terlihat positif, dengan menggunakan jasa becak kayu mereka merasa lebih aman, nyaman, lapang, terlindungi dari panas dan berusaha untuk saling membantu sesama. Sedangkan Kelurahan Ulak Karang Utara dapat dilihat dari hasil wawancara bahwa frekuensi tukang becak kayuh per harinya 5-14 kali putaran dengan hasil pendapatan yaitu lebih kurang Rp. 50.000 ,- per orang. Dalam satu minggu mereka bisa bolak-balik mengantar penumpang sampai 80-100 kali putaran dengan rata-rata pendapatan $\mathrm{Rp}$. 350.000 ,- per minggunya. Sedangkan frekuensi dalam hitungan bulan bisa sampai 150-350 kali putaran dengan rata-rata pendapatan lebih kurang $\mathrm{Rp}$. 1.200.000,- masing-masing tukang becak kayuh.

Jika kita lihat tanggapan masyarakat terkait jasa angkut becak kayuh sangat positif dalam artian permintaan pelanggan terhadap becak kayuh bisa dibilang sangat bagus, bahkan banyak masyarakat lebih memilih naik becak kayuh dari pada ojek motor maupun becak motor. Namun jika kita lihat lagi kepada pendapatan tukang becak kayuh masih 
belum bisa menyeimbangi antara pendapatan dengan pemenuhan kebutuhan sehari-hari dalam artian masih belum mampu sepenuhnya memenuhi kebutuhan hidup para tukang becak kayuh baik di Air Tawar Timur maupun di Ulak Karang Utara.

\section{PENUTUP}

Rute yang paling sering dilewati becak kayuh di Kelurahan Air Tawar Timur yaitu jl. Pinang Sori I, II dan III karena daerah ini banyak dihuni oleh mahasiswa perempuan dan tidak memiliki kendaraan pribadi dengan tarif/biaya Rp. 3.000,- per kepala. Sedangkan di Keluraha Ulak Karang Utara rute yang paling sering dilewati yaitu jl. Jakarta, karena di daerah ini ibu-ibu rumah tangga yang berbelanja setiap pagi dan mereka selalu menggunakan becak kayuh karena besar/lapang yang bisa menampung banyak barang dengan tarif/biaya Rp. 5.000,- per kepala.

Jangkauan becak kayuh Air Tawar Timur dimulai dari tempat mangkal sampai ujung jalan Garuda Tunggul Hitam (jangkauan paling jauh), sedangkan Ulak Karang Utara jangkauan paling jauh yaitu jl. Pramuka Raya Ujung. Jangkauan ini diukur dengan ongkos yang dikonversikan dengan uang.

Frekuensi permintaan terhadap jasa becak kayuh di kedua kelurahan hitungan hari 5-20 putaran dengan hasil pendapatan Rp. 50.000,- hitungan minggu 80-100 putaran dengan rata-rata pendapatan Rp. 350.000,- sedangkan frekuensi hitungan bulan 300-400 putaran dengan rata-rata pendapatan lebih kurang Rp. 1.200.000,- untuk karakteristik pelanggan mulai dari bapak-bapak, ibu-ibu, nenek-nenek, mahasiswa dan siswa pelajar. Dari hasil wawancara dapat disimpulkan bahwa tanggapan masyarakat terhadap becak kayuh sebagai jasa angkut sangat bagus, untuk Kelurahan Air Tawar Timur mereka lebih suka menggunakan jasa angkut becak dari pada ojek motor. Sedangkan untuk Kelurahan Ulak Karang Utara sudah ada pembagian blok untuk masing-masing rute/jalur untuk jasa angkut.

Berdasarkan hasil penelitian penulis melihat adanya ketidakseimbangan antara pendapatan dan pemenuhan kebutuhan hidup yang jika kita berpedoman pada intensitas kegunaan (kebutuhan primer) yang mengakibatkan tidak terpenuhinya kebutuhan pokok para tukang becak kayuh. Sebaiknya perlu pengurangan becak kayuh agar dapat menyeimbangkan antara pendapatan dan pemenuhan kebutuhan hidup. Dengan persaingan yang begitu keras demi memenuhi kebutuhan hidup lantas tidak menyurutkan semangat tukang becak kayuh untuk tetap berusaha menghasilkan rupiah demi rupiah. Setelah adanya penelitian ini, diharapkan tidak akan berhenti sampai disini saja, perlu adanya pengembangan untuk meneliti lebih lanjut dimasa yang akan mendatang khususnya terkait strategi pemenuhan kebutuhan hidup tukang becak kayuh. 


\section{DAFTAR PUSTAKA}

Anwar, Syafri. 1999. Geografi Transportasi dan Perdagangan. Padang : UNP

Bakaruddin. 2010. Dasar-Dasar Ilmu Geografi. Padang : UNP Press

Julius. 2009. Bandung, Transportasi Tradisional. Bandung: PT Remaja Rosdakarya

Khisty, C., Jotin, \& Lall, B., Kent. 2006. Dasar-Dasar Rekayasa Transportasi. Jakarta : Erlangga

Miro, Fidel. 2005. Perencanaan Transportasi untuk Mahasiswa, Perencana dan Praktisi. Jakarta : Erlangga.

Sani, Zulfiar. 2010. Transportasi (Suatu Pengantar). Jakarta : UI-Press.

Pabundu Tika, Moh. 1997. Metode Penelitian Geografi. Jakarta : Gramedia Pustaka Utama

Sugiyono, 2011. Metode Penelitian Kuantitatif Kualitatif dan $R \& D$. Bandung : Alfabeta 